\title{
CHANGES IN ICE REGIME OF JAGODNE LAKE (NORTH-EASTERN POLAND)
}

\author{
Mariusz Ptak ${ }^{1}$, Mariusz Sojka², Bogumił Nowak ${ }^{3 凶}$ \\ ${ }^{1}$ Department of Hydrology and Water Management, Adam Mickiewicz University, Krygowskiego 10, 61-680 Poznań, \\ 2 Institute of Land Improvement, Environmental Development and Geodesy, Poznań Life Science University, \\ Piątkowska 94, Poznań \\ ${ }^{3}$ Institute of Meteorology and Water Management - National Research Institute, Podleśna 61, 01-673 Warszawa
}

\begin{abstract}
Aim of the study

Indication of directions and pace of changes in ice regime of Jagodne Lake in 1975-2015. An analysis of predictability of ice phenomena in relation to stability and seasonality and an understanding mutual interactions between parameters describing ice regime of the lake.
\end{abstract}

Material and methods

Data from the Jagodne Małe water gauge station on Jagodne Lake, concerning: the dates of the beginning and the end of ice phenomena, the beginning and the end of ice cover, and the thickness of ice cover from 1975-2015. Average monthly air temperature from the IMGW-PIB synoptic station in Mikołajki. Statistical analysis based on trend analysis using the non-parametric Mann-Kendall test and the Colwell method.

\section{Results and conclusions}

The research has proven that Jagodne Lake shows some tendencies to change in ice regime over the last four decades. These trends should be identified with a successive shortening of ice season and a decrease of the thickness of ice cover. However, these changes in the case of the beginning and the end of ice phenomena (including ice cover) and the thickness of ice cover are not statistically significant. Only shortening of ice phenomena duration was observed and confirmed by the Mann-Kendall statistical test. The analyzed object reacts similarly to most of lakes, for which research on changes in icing was conducted. The observed increase of average temperatures in April had an influence on shortening of ice phenomena.

Keywords: lakes, climate change, ice cover, ice phenology

\section{INTRODUCTION}

Ice phenomena are an important element that affects functioning of lakes. The ice cover cuts off the influence of external factors, which is apparent in weakened energy exchange, changes in light conditions and lack of wind mix. In a lake ecosystem new conditions emerge that determine the course of physical, chemical and biological processes (Hutchinson, 1957). If a lake is covered by ice for a longer period, oxygen deficits may occur, and consequently lead to adverse effects on water organisms. Inland waters icing can be used directly by humans for economic and recreational purposes, for example (Wrzesiński et al., 2015).

Lake icing has been a subject of interest to many researchers around the world (Assel, Rodionov, 1998; Piliposian, Appleby, 2003; Todd, Mackay, 2003; Duguay et al., 2003; Dibike et al., 2011). In Poland, re-

凶e-mail: rugosa@op.pl 
search on ice phenomena in lakes has been conducted for over 50 years (Grześ, 1974; Pasławski, 1982; Sziwa, Jańczak, 2009; Solarski et al., 2011; Ptak, 2013; Choiński et al., 2013; Wrzesiński et al., 2013). Among various aspects of the analyses one of the main is an assessment of impact of climate change on lake regimes in regard to ice phenomena. In light of the observed changes in climate conditions (Sulikowska et al., 2016; Krużel, Ziernicka-Wojtaszek, 2016), it is important to gather detailed information on directions and pace of changes in ice processes and phenomena.

The aim of this paper was to characterize the ice regime of Jagodne Lake (north-eastern Poland) and to indicate directions and pace of its changes in the years 1975-2015. Further objectives of the study included an analysis of predictability of ice phenomena in relation to stability and seasonality and understanding of reciprocal interactions between parameters describing the ice regime of Jagodne Lake. The following research hypotheses were assumed here: (1) the time of occurrence of ice phenomena (including ice cover) is shortened in Jagodne Lake, (2) the thickness of ice cover in Jagodne Lake is reduced, (3) the dates of the beginning and the end of ice phenomena (including ice cover) have changed.

Jagodne Lake is a ribbon-type reservoir located in the Masurian Lakeland (see: Fig. 1). The lake's total area is $872.5 \mathrm{ha}$, its average depth is $8.7 \mathrm{~m}$, maximum depth $-37.4 \mathrm{~m}$ and volume $-82.71 \cdot 10^{6} \mathrm{~m}^{3}$ (Choiński, 2006).

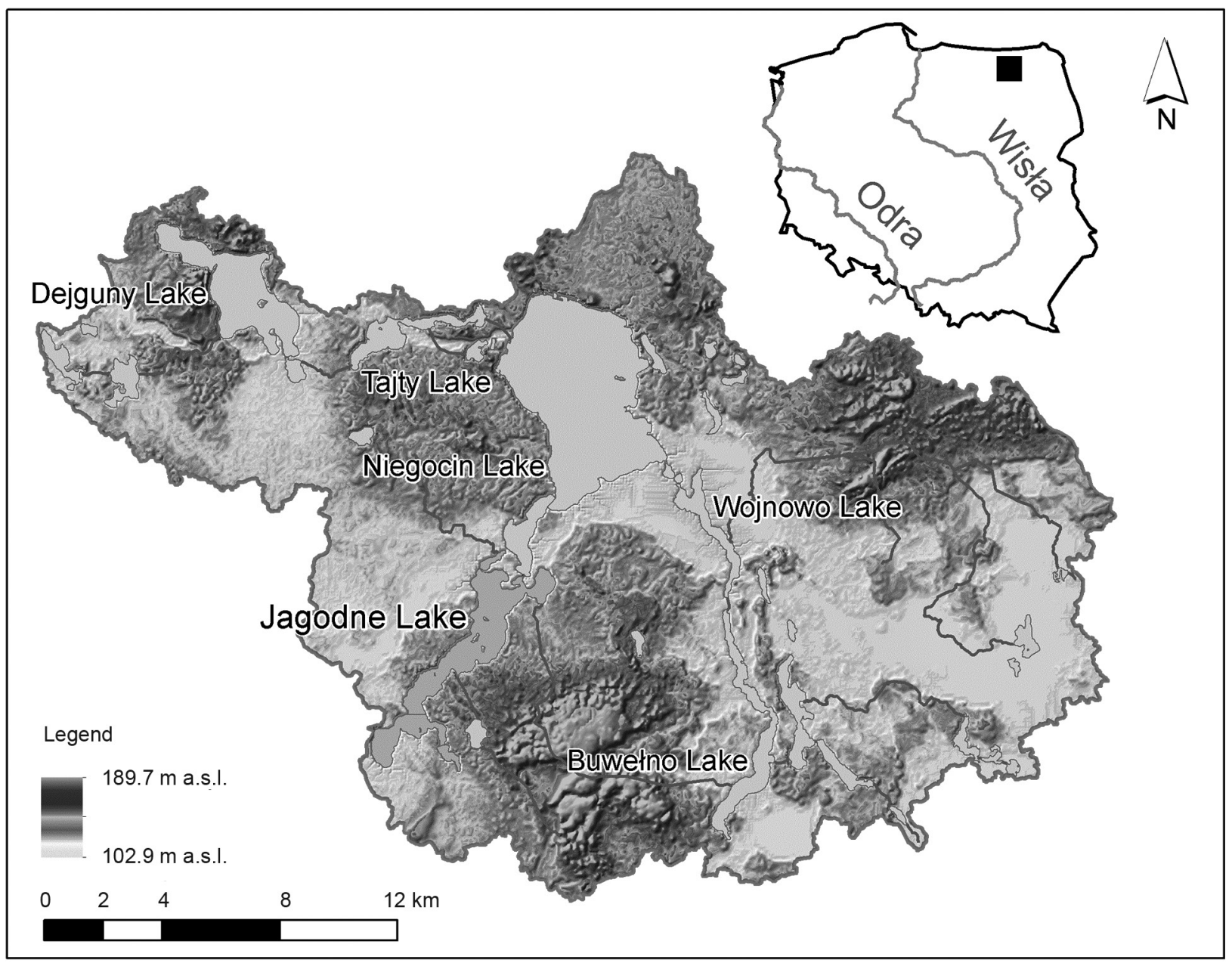

Fig. 1. Location of research object 


\section{MATERIALS AND METHODS}

The study uses data on ice phenomena recorded in water gauge station in Jagodne Małe during hydrological years 1975-2015 in Jagodne Lake made available by the Institute of Meteorology and Water Management - National Research Institute (IMGW-PIB). The obtained data set included information on: the dates of the beginning and the end of ice phenomena (PZL, KZL), the beginning and the end of ice cover (PPL, KPL) and the thickness of ice cover (GPL). On the basis of the obtained data, ice phenomena duration (CTZL), icing duration (CTPL), the time from the occurrence of ice phenomena to the occurrence of ice cover (PPL-PZL) and the time from the end of ice cover to the end of ice phenomena (KZL-KPL) were calculated for individual years. The dates of the beginning and the end of ice phenomena and ice cover were given in relation to the beginning of hydrological year (the number of days). With regard to climate data, average monthly air temperatures from the years 1975-2015 from the IMGWPIB synoptic station in Mikołajki were used. This station is located about $15 \mathrm{~km}$ south-west of Jagodne Lake.

The obtained data were subjected to statistical analysis. In order to determine the tendency of changes in ice phenomena on Jagodne Lake, an analysis of linear trends was performed using the non-parametric Mann-Kendall (MK) test (Kendall and Stuart, 1966) based on the $S$ statistics.

$$
S=\sum_{k=1}^{n-1} \sum_{j=k+1}^{n} \operatorname{sign}\left(x_{j}-x_{k}\right)
$$

given that:

$$
\operatorname{sign}\left(x_{j}-x_{k}\right)=\left\{\begin{array}{l}
1 \text { for }\left(x_{j}-x_{k}\right)>0 \\
0 \text { for }\left(x_{j}-x_{k}\right)=0 \\
-1 \text { for }\left(x_{j}-x_{k}\right)<0
\end{array}\right.
$$

given that:

$$
n \text { - number of components of time series, }
$$

The zero hypothesis $H_{0}$ was assumed with no monotonic data trend, while an alternative hypothesis $H_{l}$ assumes that the trend exists. The value of normalized $\mathrm{Z}$ statistics, allowing verification of the hypotheses, was calculated from the equation:

$$
Z=\frac{S-\operatorname{sign}(S)}{\operatorname{Var}(S)^{0.5}}
$$

given that:

$\operatorname{Var}(S)$ - variance $S$ calculated from the equation,

$$
\operatorname{Var}(S)=\frac{1}{18}(n \cdot(n-1) \cdot(2 n+5))
$$

A trend is increasing if $Z$ is positive, or decreasing if $Z$ is negative. Based on the normalized $Z$ statistics, test probability $p$ was calculated. If its value is lower than an adopted level of significance, then the trend is statistically significant. An analysis of significance of trends was run for four significance levels: $0.1,0.05,0.01$ and 0.001 . Average values of changes in the analysed variables, i.e.: ice cover thickness (GPL), ice phenomena duration (CTZL), ice cover duration (CTPL), the dates of the beginning and the end of occurrence of ice phenomena (TPZL, TKZL) and the dates of the beginning and the end of occurrence of ice cover (TPPL, TKPL) in the years 1975-2015 was calculated on basis of the non-parametric Sen's test (Gilbert, 1987). The Sen's test is commonly used to assess magnitude of changes over time, which can be expressed in a general formula $f(t)=Q t+B$, where $Q$ is slope coefficient and $B$ is constant. Slope $Q_{i}$ between two points of time series is calculated from the equation:

$$
Q_{i}=\frac{x_{j}-x_{k}}{j-k}, k \neq j
$$

For time series comprised of $n$ elements there is $N=n(n-1) / 2$ of $Q_{i}$. According to Sen, a general estimator of $Q$ slope is a median of the $N$ set of $Q_{i}$ value and can be calculated from the formula:

$$
Q=\left\{\begin{array}{c}
Q_{(N+1) / 2}, N \text { odd numbers } \\
\frac{Q_{N / 2}+Q_{(N+2) / 2}}{2}, N \text { even numbers }
\end{array}\right.
$$

The value of $B$ constant was calculated as a median from $x_{i}-Q t_{i}$. The Sen's test is less sensitive to extreme observations than the method of least squares.

An analogous course of action was adopted for determining directions and rates of changes in average 
monthly air temperatures at the Mikołajki station. In order to fully describe the course of ice processes and to determine their mutual dependence, an analysis of correlation between the examined parameters was carried out.

Seasonal variability of ice phenomena occurrences (i.e. PZL, KZL, PPL, KPL with regard to their CTZL and CTPL duration) in Jogodne Lake was determined by the Colwell method (1974), in which three indicators are evaluated: predictability $(\mathrm{P})$, stability $(\mathrm{C})$ and seasonality $(\mathrm{M})$. For the research a $10 \times 12$ matrix ( 10 columns - time intervals for the beginning and the end of ice phenomena and ice cover, 12 rows - the size of the phenomenon, icing and ice cover duration, and ice thickness) was created. The P, C and M indicators assume value 0 , when probability of occurrence of a given phenomenon at an indicated time and with a given intensity is equal in all intervals. The stability indicator $C$ shows that the variable has a tendency to remain in a certain state and assumes value 1 , when a phenomenon has a constant intensity (adopting values from a single class interval $S_{i}$ ). The seasonality indicator $M$ shows that the variable has a tendency to occur in a given time and assumes value 1 , when a phenomenon appears at the same time (occurs within a single time interval $T_{i}$ ). The predictability indicator $\mathrm{P}$ describes a possibility of predicting a phenomenon in relation to its occurrence and intensity.

\section{RESULTS AND DISCUSSION}

Usually, ice phenomena in Jagodne Lake in the analysed period of 1975-2015 begin at the end of the fifth decade of a hydrological year (around December 18th). Ice phenomena were not recorded until the middle of the second decade (November 15th), and at the beginning of the eleventh decade (February 9th) at the latest. The recession of ice phenomena in the reservoir was recorded in the middle of the seventh decade (January 5th) at the earliest, while the longest they lasted was until the beginning of the nineteenth decade (April 30th). The average time of ice phenomena regression is the middle of the fifteenth decade (March 24th). The ice phenomena duration in the considered period ranged from 34 to 148 days, with an average of about 96 days. The ice cover on Jagodne Lake appeared towards the end of the second decade
(November 18th) at the earliest, and in the end of the eleventh decade (February 16th) at the latest. In the analysed period the ice cover appeared on average at the end of the sixth decade (December 28th), and generally retreated in the middle of the fourteenth decade (March 15th) with volatility ranging between the end of the sixth decade (December 29th) and the end of the seventeenth decade (April 19th). Ice cover maintained on the reservoir on average for 78 days, with a minimum of 9 days and a maximum of 135 days. The maximum thickness of ice cover in the analysed multi-year period ranged from 7 to $56 \mathrm{~cm}$, with an average value of $29 \mathrm{~cm}$. Correlation analysis showed correlations between the studied parameters characterizing the occurrence of ice phenomena in Jagodne Lake (Table 1). The maximum thickness of ice cover was inversely proportional to the beginning of icing on the reservoir and directly proportional to the end of icing and ice phenomena duration, including icing duration.

Table. 1. Correlations between parameters characterising the ice regime of Jagodne Lake $\left(r_{\text {crit }}=0.308\right.$ for $\left.\alpha=0.05\right)$

\begin{tabular}{|c|c|c|c|c|c|c|c|}
\hline Parameter & PZL & KZL & PPL & KPL & CTZL & CTPL & GPL \\
\hline PZL & - & 0.11 & 0.80 & 0.09 & -0.55 & -0.43 & -0.22 \\
\hline KZL & 0.11 & - & 0.07 & 0.96 & 0.77 & 0.73 & 0.63 \\
\hline PPL & 0.80 & 0.07 & - & 0.06 & -0.46 & -0.59 & -0.32 \\
\hline KPL & 0.09 & 0.96 & 0.06 & - & 0.74 & 0.78 & 0.67 \\
\hline CTZL & -0.55 & 0.77 & -0.46 & 0.74 & - & 0.89 & 0.67 \\
\hline CTPL & -0.43 & 0.73 & -0.59 & 0.78 & 0.89 & - & 0.75 \\
\hline GPL & -0.22 & 0.63 & -0.32 & 0.67 & 0.67 & 0.75 & घ \\
\hline
\end{tabular}

The analysis of trends has shown that in the last forty years the conditions for lake icing have evolved. Referring to individual indicators, it was observed that ice phenomena in the reservoir appear later - by an average of about 3 days $\cdot \mathrm{dec}^{-1}$, and on the other hand their regression is noted faster - by an average of about 3 days $\cdot \operatorname{dec}^{-1}$ (see: Fig. 2). In consequence, ice phenomena duration shortened - in total by 6 days $\cdot \mathrm{dec}^{-1}$ (see: Fig. 3). Although changes in the course of ice phenomena over the years are noticeable, an analysis of trends has shown that changes in the dates of the beginning and the end of the occurrence of ice phenomena are not statistically significant (see: Table 2). 
Ptak, M., Sojka, M., Nowak B. (2019). Changes in ice regime of Jagodne Lake (north-eastern Poland). Acta Sci. Pol., Formatio Circumiectus, 18(1), 89-100. DOI: http://dx.doi.org/10.15576/ASP.FC/2019.18.1.89

A

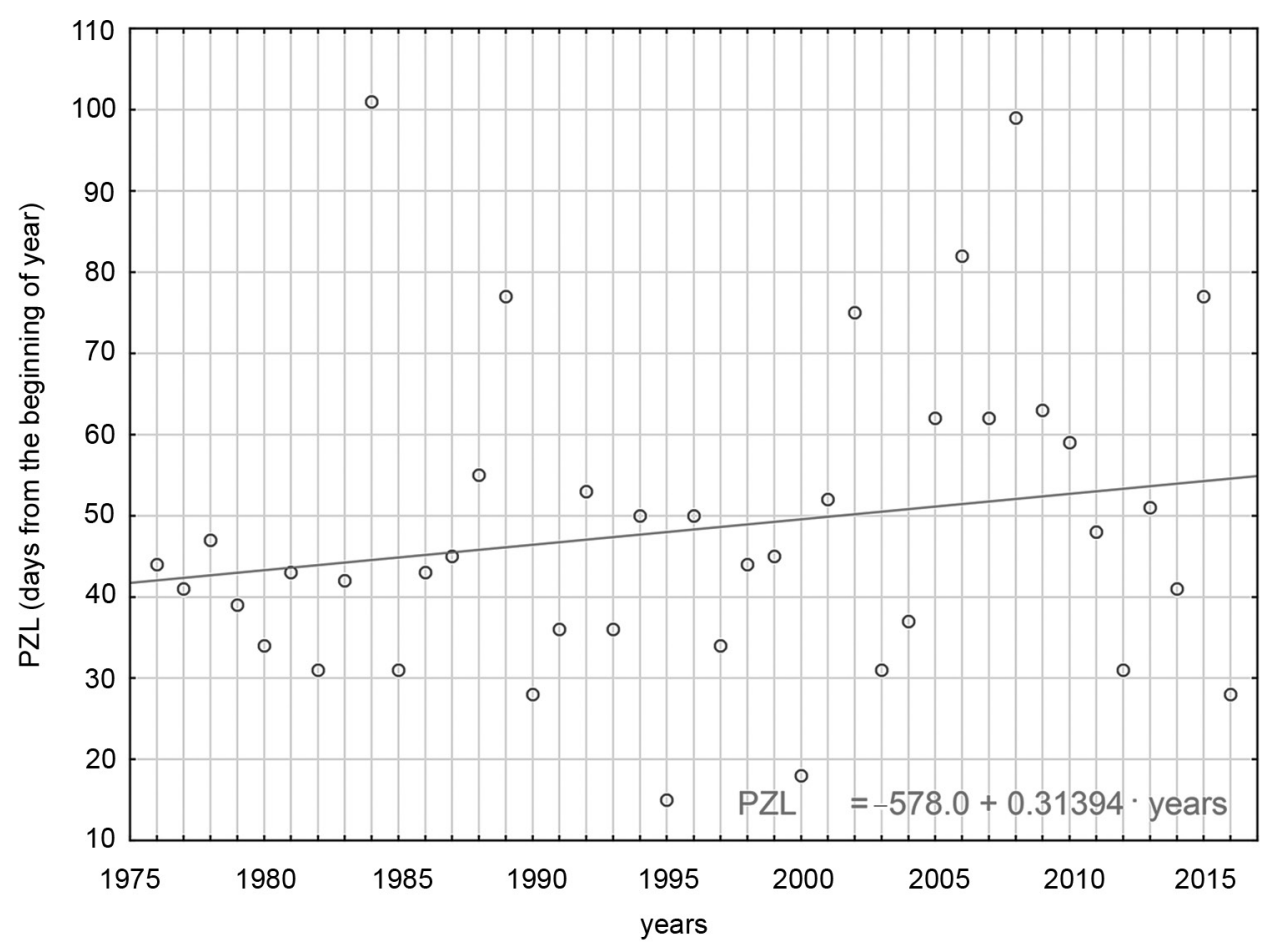

B

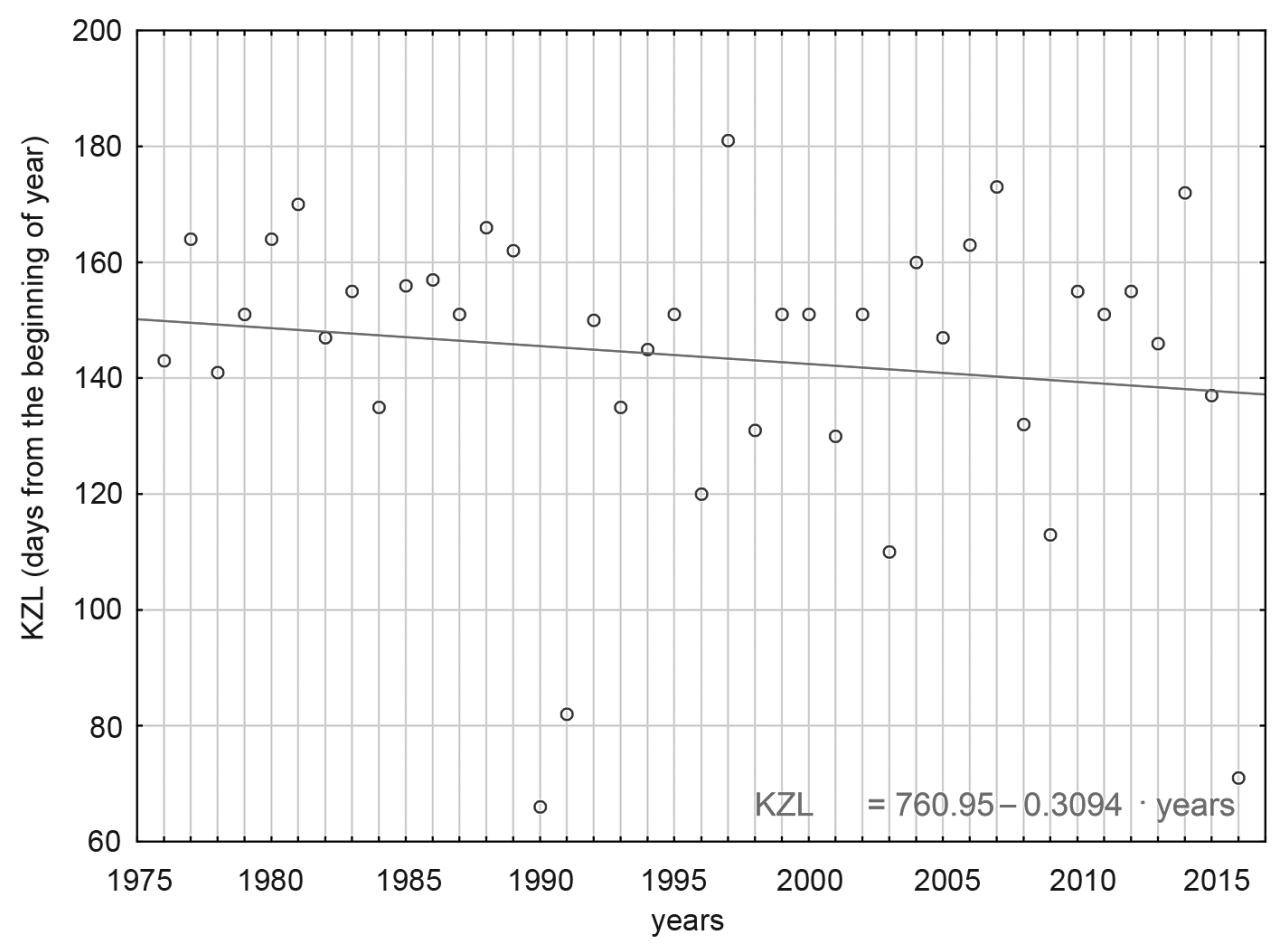

Fig. 2. Beginning (a) and end (b) of ice phenomena on Jagodne Lake in 1975-2015 


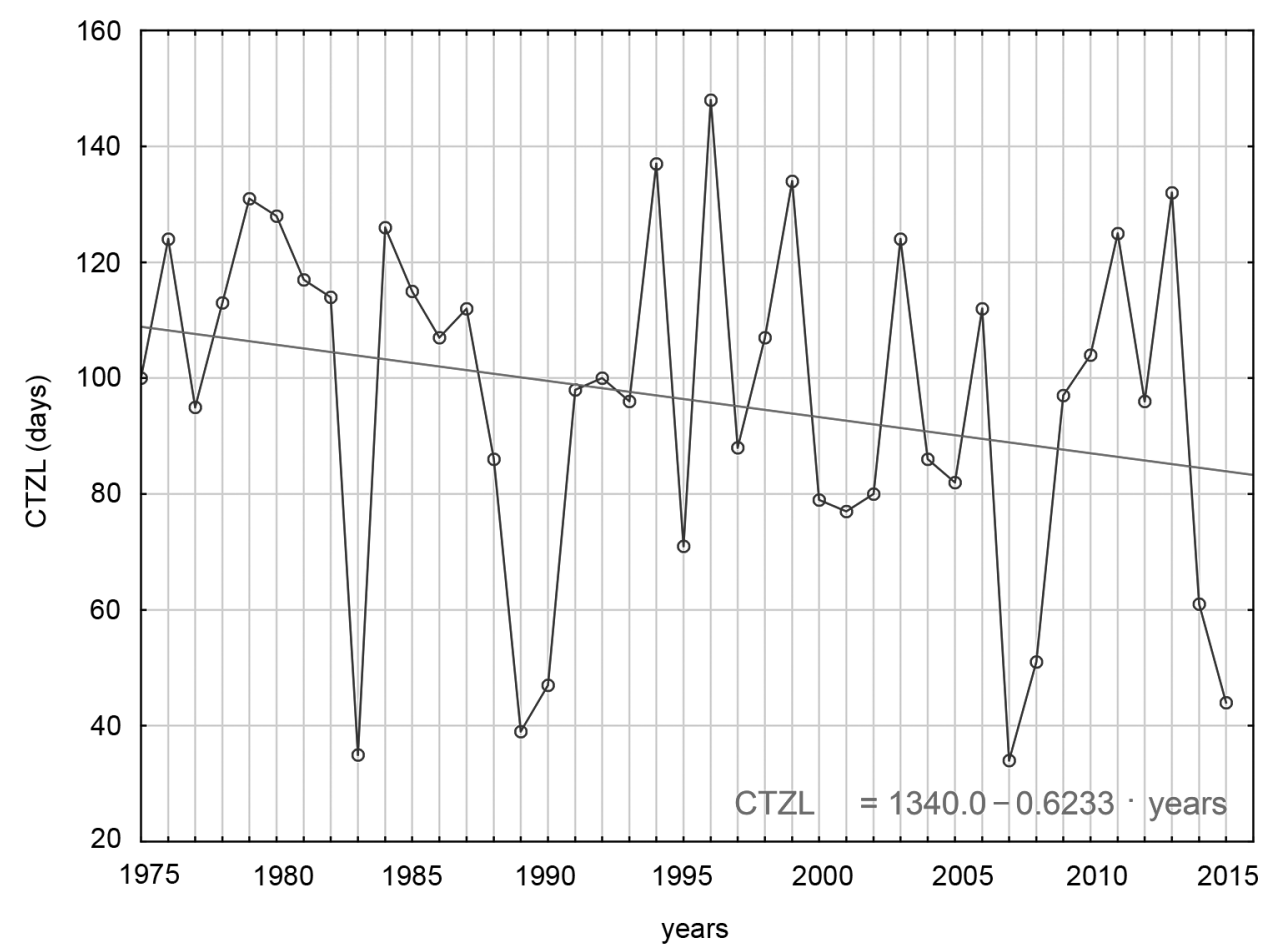

Fig. 3. Ice phenomena duration on Jagodne Lake in 1975-2015

Statistically significant changes at the level of $p_{\alpha}=0.1$ were observed in relation to ice phenomena duration, which have shortened over the years.

Table 2. Assessment of trends of ice phenomena on Jagodne Lake in 1975-2015

\begin{tabular}{|l|c|c|c|c|}
\hline Parameter & $\begin{array}{c}\text { S Mann- } \\
\text {-Kendall }\end{array}$ & Z test & $\mathrm{p}$ & $\begin{array}{c}\text { Trend } \\
\text { significance at } \\
\text { the level } \alpha=0.01\end{array}$ \\
\hline PZL & 118 & 1.316 & 0.1883 & - \\
\hline KZL & -71 & -0.789 & 0.4302 & - \\
\hline PPL & 39 & 0.427 & 0.6693 & - \\
\hline KPL & -95 & -1.057 & 0.2906 & - \\
\hline CTZL & -156 & -1.742 & 0.0816 & decreasing \\
\hline CTPL & -100 & -1.113 & 0.2659 & - \\
\hline GPL & -128 & -1.428 & 0.1533 & - \\
\hline
\end{tabular}

Similar directions of changes were recorded in relation to the occurrence of ice cover on the lake. It was observed that ice cover on the lake has formed in the following years with a delay of about $1 \mathrm{day} \cdot \mathrm{dec}^{-1}$, and its disappearance was faster by about 4 days $\cdot \operatorname{dec}^{-1}$ (see: Fig. 4). In total, ice cover duration in the years 1975-2015 decreased by an average of 5 days $\cdot \operatorname{dec}^{-1}$ (see: Fig. 5). Shortening of ice cover duration was reflected in the thickness of ice cover. Its maximum thickness was being reduced at a rate approx. to $2 \mathrm{~cm} \cdot \operatorname{dec}^{-1}$ (see: Fig. 6). The presented changes, characterizing the occurrence of ice cover, were not statistically significant.

The analysis of changes in air temperature for the Mikołajki station (about $15 \mathrm{~km}$ away from the test object) was carried out considering the relation between lake icing and climate conditions (Wrzesiński et al., 2015). As it was indicated by the course of the average annual temperature in the examined multi-year, it has increased by an average of about $1.4^{\circ} \mathrm{C}$. Changes in the average monthly temperature in the period from November to March were not statistically significant, although there was an upward trend on average of about $0.2^{\circ} \mathrm{C} \cdot \mathrm{dec}^{-1}$. The largest changes in temperature occurred in April and July - on average about 
Ptak, M., Sojka, M., Nowak B. (2019). Changes in ice regime of Jagodne Lake (north-eastern Poland). Acta Sci. Pol., Formatio Circumiectus, 18(1), 89-100. DOI: http://dx.doi.org/10.15576/ASP.FC/2019.18.1.89

A

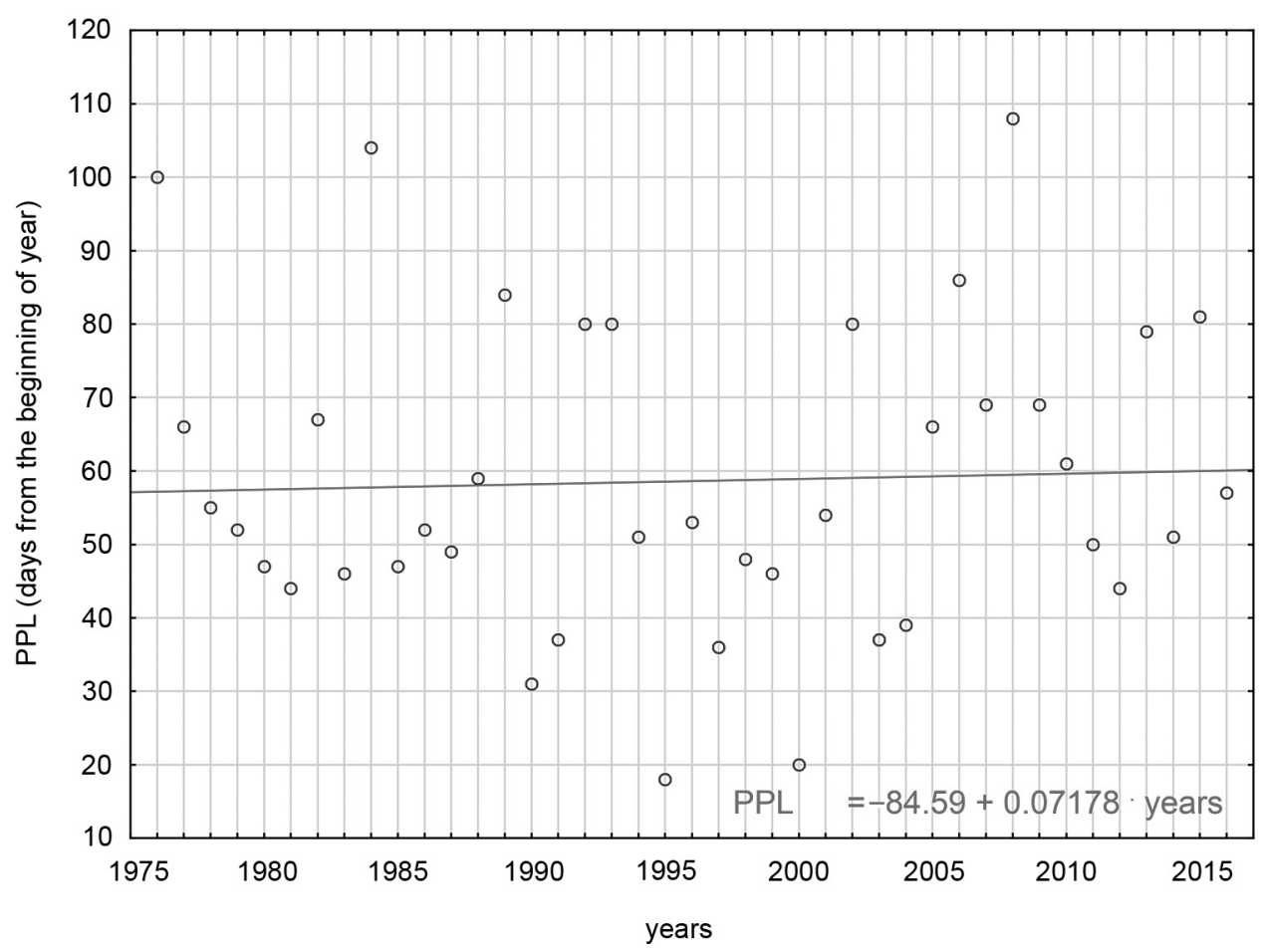

B

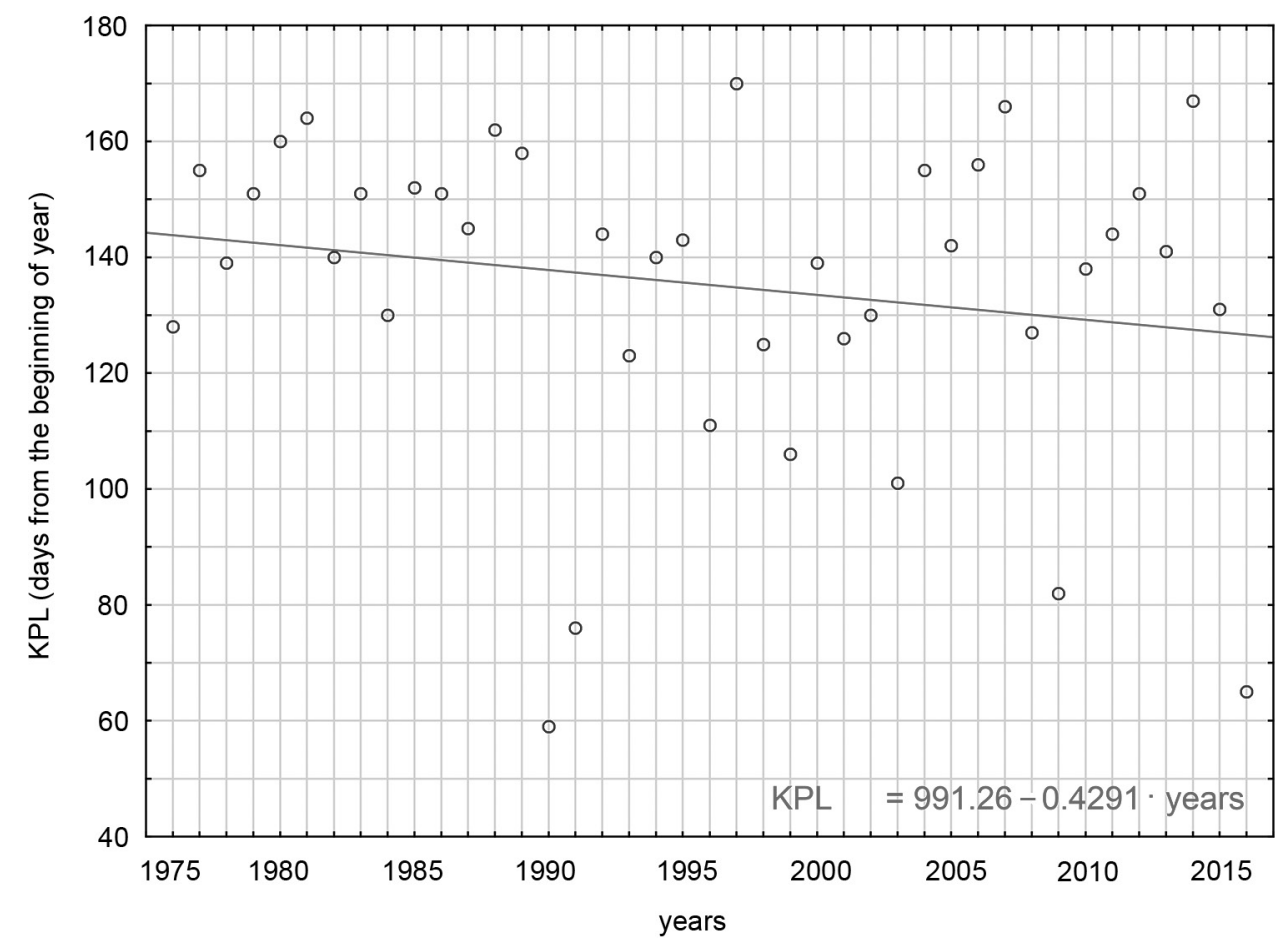

Fig. 4. Beginning (a) and end (b) of ice cover on Jagodne Lake in 1975-2015 
Ptak, M., Sojka, M., Nowak B. (2019). Changes in ice regime of Jagodne Lake (north-eastern Poland). Acta Sci. Pol., Formatio Circumiectus, 18(1), 89-100. DOI: http://dx.doi.org/10.15576/ASP.FC/2019.18.1.89

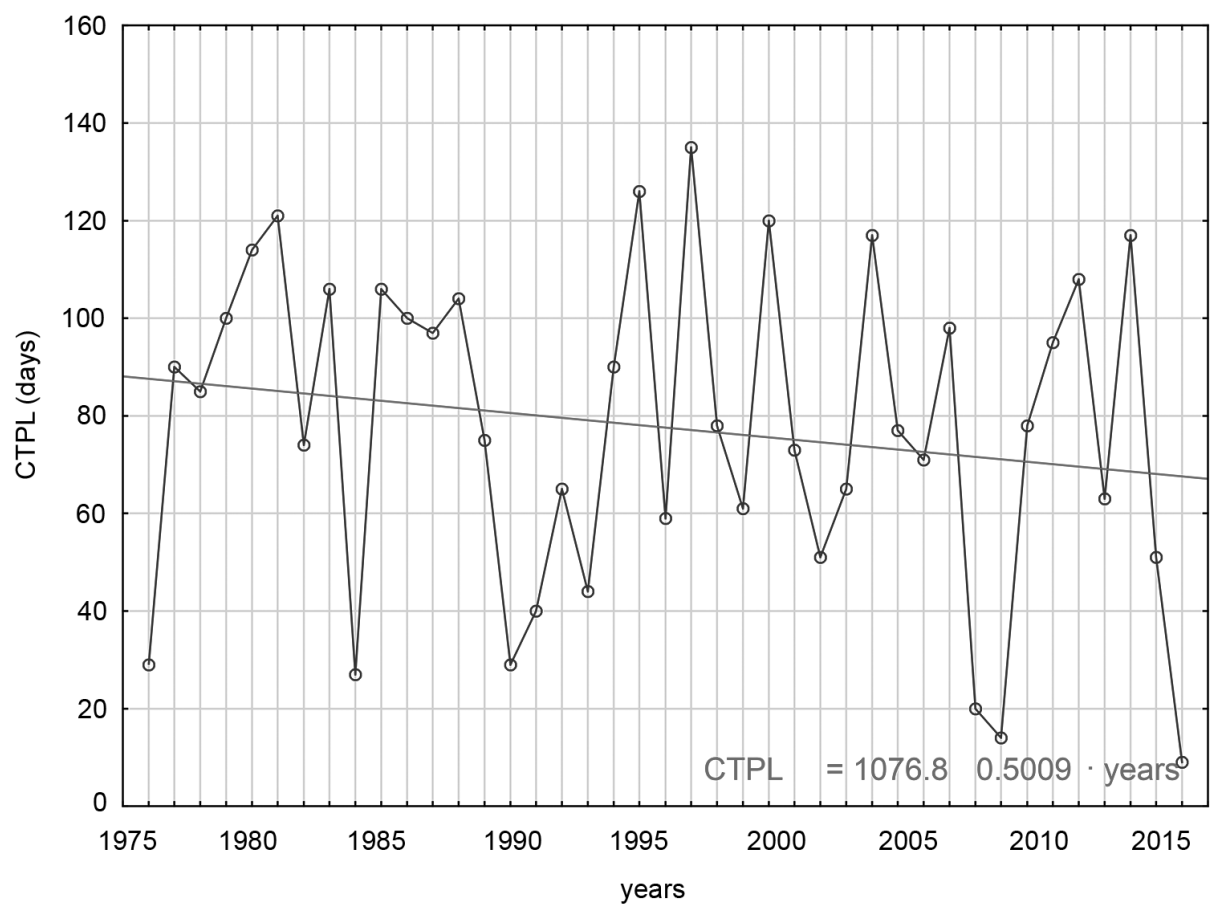

Fig. 5. Ice cover duration on Jagodne Lake in 1975-2015

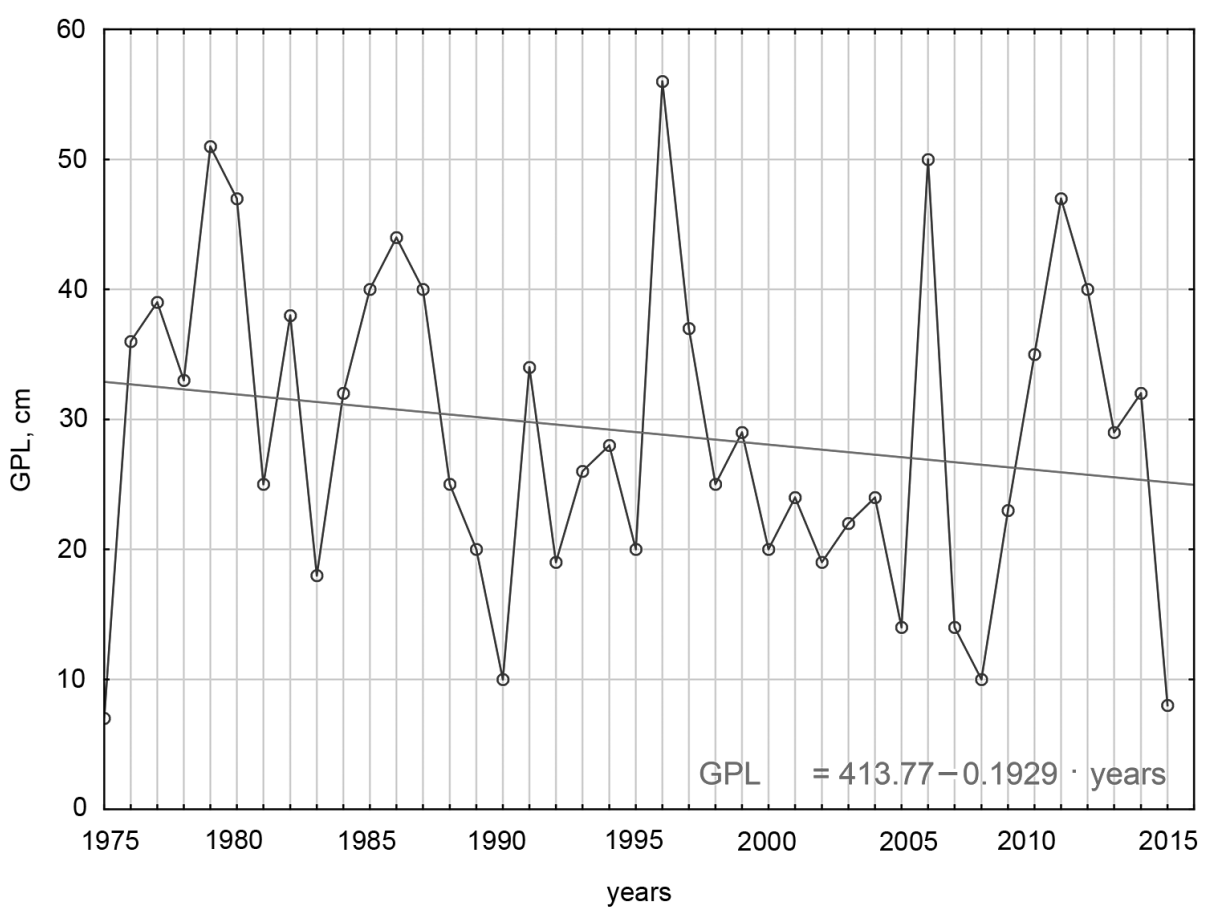

Fig. 6. Maximum thickness of ice cover on Jagodne Lake in 1975-2015 
$0.7^{\circ} \mathrm{C} \cdot \mathrm{dec}^{-1}$, in August $-0.5^{\circ} \mathrm{C} \cdot \mathrm{dek}^{-1}$ and in June $0.3^{\circ} \mathrm{C} \cdot \mathrm{dek}^{-1}$, which were statistically significant at $\alpha=0.05$. From the point of view of the occurrence of ice phenomena, temperature increase in April seems to be significant, because it contributed to acceleration of the dates of ice phenomena decline from the reservoir.

Seasonal analysis of the occurrence of ice phenomena in Lake Jagodne was carried out in pairs of PZL-CTZL, KZL-CTZL, PPL-CTPL, KPL-CTPL, PPL-GPL, and KPL-GPL. For each case, a matrix was created, in which columns represented time intervals for PZL, KZL, PPL and KPL and rows - the size of a phenomenon, i.e. CTZL, CTPL and GPL. The matrix had in every case 10 intervals and 12 sections regarding the size of a phenomenon. The results are presented in Table 3.

Table 3. Results of stability analysis of the ice regime of Jagodne Lake on basis of the Colwell method

\begin{tabular}{|c|c|c|c|c|c|c|}
\hline Indicator & $\begin{array}{c}\text { PLZ- } \\
\text { CTZL }\end{array}$ & $\begin{array}{c}\text { KZL- } \\
\text { CTZL }\end{array}$ & $\begin{array}{c}\text { PPL- } \\
\text { CTPL }\end{array}$ & $\begin{array}{c}\text { KPL- } \\
\text { CTPL }\end{array}$ & $\begin{array}{c}\text { PPL- } \\
\text { GPL }\end{array}$ & $\begin{array}{c}\text { KPL- } \\
\text { GPL }\end{array}$ \\
\hline C (-) & 0.07 & 0.07 & 0.04 & 0.04 & 0.03 & 0.03 \\
\hline M (-) & 0.62 & 0.40 & 0.44 & 0.47 & 0.39 & 0.36 \\
\hline P (-) & 0.69 & 0.47 & 0.48 & 0.51 & 0.43 & 0.39 \\
\hline
\end{tabular}

The obtained results prove that the most predictable phenomenon in the analysed multi-year period were the dates of the occurrence of ice phenomena together with ice phenomena duration $(\mathrm{P}=0.69)$. It is possible to predict the date of occurrence of ice phenomena $(\mathrm{M}=0.62)$ with a higher probability, than this phenomenon duration on the lake $(C=0.07)$. Ice phenomena appear in the lake between 1st and 20th of December (23 out of 41 cases), whereas ice phenomena duration was evenly distributed within individual classes. It is the least probable to predict the date of disappearance of ice cover in relation with its maximum thickness $(\mathrm{P}=0.39)$. It is also easier to indicate the date of ice cover retreat $(\mathrm{M}=0.36)$ - usually from March 19th to April 11th (21 out of 41 cases) - than the maximum thickness of ice cover $(\mathrm{C}=0.03)$. In other cases, predictability indicator rates were on a similar level, from 0.43 to 0.51 . It suggests that ice phenomena duration, including ice cover and maximum ice thickness, is unstable. Especially if we take into account the dates of the beginning and the end of the occurrence of ice phenomena and ice cover.

Generally, it can be concluded that ice season on Lake Jagodne over the past several decades tends to shorten. These changes, as proven by statistical analyses, are generally not statistically significant, though. Referring to the current research on lake icing in Poland, at least a few studies should be mentioned. Marszelewski and Skowron (2006) after studying six lakes in northern Poland noted, among others, faster disappearance of ice cover and reduction of the maximum thickness of ice cover. Choiński et al. (2014) on the example of five lakes have shown that there was an average reduction in ice phenomena duration (by 5 days $\cdot \operatorname{dek}^{-1}$ ), ice cover (by 5.5 days $\cdot \operatorname{dek}^{-1}$ ) and reduction of the maximum thickness of cover ice (about $\left.2.1 \mathrm{~cm} \cdot \mathrm{dek}^{-1}\right)$. With regard to a group of a dozen or so lakes, Choiński et al. (2015) pointed to the later dates of ice appearance and the earlier of disappearance. Ice cover duration shortens and its thickness reduction was recorded. The results presented in this paper are in accordance with those in Nowak et al. (2018) regarding four lakes situated in central Poland. An alpine lake Morskie Oko in the Tatra Mountains, the ice season of which has shortened, over the last decades behaves similarly to the lowland lakes. According to Ptak et al. (2017), duration of ice phenomena and ice cover is getting shorter at an average rate of $10 \mathrm{days} \cdot \mathrm{dek}^{-1}$.

The results obtained in the study are consistent with the majority of observations held in different regions of the world. Bernhardt et al. (2012), analysing ice conditions of lakes in Germany (Berlin-Brandenburg), showed that ice cover forms later and declines earlier, has a shorter duration and pointed to an increase in winters without ice. Benson et al. (2012) on grounds of an analysis of 75 lakes located in the Northern Hemisphere found that the change rate of dates of ice cover forming and declining came later by 0.3 to 1.6 days $\cdot$ dek $^{-1}$ in the first case and earlier by 0,7 to 4.3 days $\cdot \operatorname{dek}^{-1}$ in the second case. The reaction of shallow lakes in the northern part of Alaska to climate conditions was studied by Surdu et al. (2014). It was determined that in consequence of later ice forming (by 5.9 days) and earlier ice decline (17.7-18.6 days) in the years 1950-2011 ice cover duration was shortened by 24 days $\left(3.9\right.$ days $\left.\cdot \operatorname{dek}^{-1}\right)$. In the case of a subalpine Lake Lunz, Kainz et al. (2017) found that 
ice cover formed later at the rate of 1.7 days $\cdot \mathrm{dek}^{-1}$ and its decline was faster by $1.8 \mathrm{days} \cdot \mathrm{dek}^{-1}$. In the case of Qinghai Lake (China), Cai et al. (2017) basing on data from the last 38 years noted that ice cover duration has reduced by 21.2 days $\left(5.6\right.$ days $\left.\cdot \operatorname{dek}^{-1}\right)$.

Lakes are complex ecosystems, where changes to any process can cause a transformation of the others, ultimately affecting the functioning of an entire system. As Kintisch (2015) points out, faster ice cover disappearance leads the lakes that normally freeze in winter to about twice as fast heating as the lakes that are not affected by such process. Ptak et al. (2018) emphasize the role of ice season shortening on an increase in temperature of lakes in Poland. An earlier decline of ice cover has an impact on faster formation of thermal stratification, and thus for a longer period only a part of water, including epilimnion, is heated. This has following consequences: changes in lake mix, decreased solubility of gases in lake water, higher probability of algal blooms, etc. Numerous studies indicate that the occurrence of ice cover and its disappearance are important for biological processes (Adrian et al., 1999; Pełechata et al., 2015). The models of changes to the ice regime indicate that further ice cover shortening will continue (Gebre et al., 2014; Hewitt et al., 2017). In this light, and taking into account the increase in air temperature at the Mikołajki station, it can be stated that the examined lake will behave similarly in the near future.

\section{CONCLUSIONS}

Summarising the research, it can be concluded that Jagodne Lake over the last decades has shown tendencies to change the ice regime. Ice phenomena continue to occur later (on average by 3 days $\cdot \operatorname{dek}^{-1}$ ), and they decline faster (also by 3 days $\cdot \mathrm{dek}^{-1}$ ). In consequence, ice phenomena duration is shortened - in total by 6 days $\cdot \operatorname{dek}^{-1}$ (see: Fig. 3). Similar results were obtained for ice cover, which starts to appear a bit later (on average 1 day $\cdot \mathrm{dek}^{-1}$ ) and disappears faster (on average over 4 days $\cdot \mathrm{dek}^{-1}$ ). In total, ice cover duration in the 1975-2015 period has decreased by an average of 5 days $\cdot$ dek $^{-1}$ (see: Fig. 5). The shortening of the ice cover duration was reflected in ice cover thickness. The maximum ice thickness was being reduced at a rate of nearly $2 \mathrm{~cm} \cdot \mathrm{dek}^{-1}$.
These trends should be related to successive shortening of the ice season and decreasing of ice cover thickness. However, changes of the beginning and the end of ice phenomena (including ice cover) and ice cover thickness are not statistically significant. Only ice phenomena duration shortening was observed. Ice phenomena in Jagodne Lake have been monitored since 1975, so a longer measurement sequence will be available in ten-twenty years.

The analysis of changes in air temperature at the Mikołajki station indicate that climate warming observed in April can affect ice phenomena duration. In the remaining months of winter of the hydrological half-year there were no changes in air temperature.

The analysis of seasonality of ice phenomena in Jagodne Lake showed that the highest predictability characterizes the beginning of ice phenomena. Whereas, predicting the date of beginning of ice cover occurrence and the dates of ending of ice phenomena and ice cover becomes more difficult.

The analysed object reacts similarly to the most of lakes, which were studied in regard to changes in icing. This applies to lakes both in Poland and in different regions around the world, while it is important to underline that the pace of these changes differs depending on local conditions and individual lakes. Modifications in the ice regime are poorly visible due to the fact that thermal conditions have been transformed mainly in the summer months of the hydrological half-year. The observed increase in average temperatures in April influenced the shortening of ice phenomena duration, including ice cover. The presence of ice cover is a key element that determines the functioning of lake ecosystems in latitudes of temperate zones. A number of interdependent processes depend on the length of storage of ice cover - no only in winter season. These changes will lead to further transformation, and its effects due to the network of interrelated relations (biotic and abiotic) are difficult to predict.

\section{REFERENCES}

Adrian, R., Walz, N., Hintze, T., Hoeg, S., Rusche, R. (1999). Effects of ice duration on plankton succession during spring in a shallow polymictic lake. Freshwater Biology, 41, 3, 621-632. 
Assel, R., Rodionov, S. (1998). Atmospheric teleconnections for annual maximum ice cover on the laurentian great lakes. International Journal of Climatology, 18, 4, 425-442.

Benson, B.J., Magnuson, J.J., Jensen, O.P., Card, V.M., Hodgkins, G., Korhonen, J., Livingstone, D.M., Stewart, K.M., Weyhenmeyer, G.A., Granin, N.G. (2012). Extreme events, trends, and variability in Northern Hemisphere lake-ice phenology (1855-2005). Climatic Change, 112, 2, 299-323.

Bernhardt, J., Engelhardt, C., Kirillin, G., Matschullat, J. (2012). Lake ice phenology in Berlin-Brandenburg from 1947-2007: Observations and model hindcasts. Climatic Change, 112, 3-4, 791-817.

Cai, Y., Ke, C.-Q., Duan, Z. (2017). Monitoring ice variations in Qinghai Lake from 1979 to 2016 using passive microwave remote sensing data. Science of the Total Environment, 607-608: 120-131.

Choiński, A. (2006). Katalog jezior Polski. Poznań: Wyd. Nauk UAM.

Choiński, A., Ptak, M., Skowron, R., Strzelczak, A. (2015). Changes in ice phenology on polish lakes from 1961-2010 related to location and morphometry. Limnologica, 53, 42-49.

Choiński, A., Ptak, M. Strzelczak, A. (2013). Areal variation in ice cover thickness on lake Morskie Oko (Tatra Mountains). Carpathian Journal of Earth and Environmental Sciences, 8, 3, 97-102 .

Colwell, R. K. (1974). Predictability, constancy, and contingency of periodic phenomena. Ecology, 55, 5, 1148-1153.

Dibike, Y., Prowse, T., Saloranta, T., Ahmed, R. (2011). Response of Northern Hemisphere lake-ice cover and lake-water thermal structure patterns to a changing climate. Hydrological Processes, 25, 19, 2942-2953.

Duguay, C.R., Flato, G.M., Jeffries, M.O., Ménard, P., Morris, K., Rouse, W.R. (2003). Ice-cover variability on shallow lakes at high latitudes: Model simulations and observations. Hydrological Processes, 17, 17, 3465 -3483 .

Gebre, S., Boissy, T., Alfredsen, K. (2014). Sensitivity of lake ice regimes to climate change in the Nordic region. Cryosphere, 8, 4, 1589-1605.

Gilbert, R.O. (1987). Statistical methods for environmental pollution monitoring. New York: Van Nostrand Reinhold.

Grześ, M. (1974). Badania nad termiką i zlodzeniem jeziora Gopło. Dokumentacja Geograficzna, 3, IG i PZ PAN, 56.

Hewitt, B.A., Lopez, L.S., Gaibisels, K.M., Murdoch, A., Higgins, S.N., Magnuson, J.J., Paterson, A.M., Rusak, J.A., Yao, H., Sharma, S. (2018). Historical trends, drivers, and future projections of ice phenology in small north temperate lakes in the Laurentian Great Lakes Region. Water, 10, 1, 70 .

Hutchinson, G.E. (1957). A treatise on limnology, New YorkLondon, Geography, Physics and Chemistry, 1015.

Kainz, M.J., Ptacnik, R., Rasconi, S., Hager, H.H. (2017). Irregular changes in lake surface water temperature and ice cover in subalpine Lake Lunz, Austria. Inland Waters, 7, 1, 27-33.

Kendall, M. G., Stuart, A. (1955). The advanced theory of statistics, 3, 1966. GRIFFIN ed., London.

Kintisch, E. (2015). Earth's lakes are warming faster than its air: First ever global survey reveals summer lake temperatures rising at an alarming rate. Science, 350, 1449.

Krużel, J., Ziernicka-Wojtaszek, A. (2016). Diversity of air temperature in Poland in the years 1971-2010. Journal of Ecological Engineering, 17, 5, 227-231.

Nowak, B., Nowak, D., Ptak, M. (2018). Variability and course of occurrence of ice cover on selected lakes of the Gnieźnieńskie Lakeland (Central Poland) in the period 1976-2015, E3S Web Conf., 44, Article Number: 00126.

Pasławski, Z. (1982). Zlodzenie jezior w Polsce. Przegląd Geofizyczny, 27, 1-2, 79-92.

Pełechata, A., Pełechaty, M., Pukacz, A. (2015). Winter temperature and shifts in phytoplankton assemblages in a small Chara-lake. Aquatic Botany, 124, 10-18.

Piliposian, G.T., Appleby, P.G. (2003). A model of the impact of winter ice cover on pollutant concentrations and fluxes in mountain lakes. Water, Air, and Soil Pollution, $144,1-4,101-115$.

Ptak, M. (2013). Zmienność temperatury i przebiegu zjawisk lodowych jeziora Łebsko i Gardno (Słowiński Park Narodowy). Parki Narodowe i Rezerwaty Przyrody, 32, 2, 45-55.

Ptak, M., Sojka, M., Choiński, A., Nowak, B. (2018). Effect of environmental conditions and morphometric parameters on surface water temperature in Polish lakes. Water, 10,580 .

Ptak, M., Wrzesiński, D., Choiński, A. (2017). Long-term changes in the hydrological regime of high mountain lake Morskie Oko (Tatra Mountains, Central Europe). Journal of Hydrology and Hydromechanics, 65, 2, 146-153 .

Salmi, T., Maatta, A., Anttila, P., Ruoho-Airola, T., Amnell, T. (2002). Detecting Trends of Annual Values of Atmospheric Pollutants by the Mann-Kendall Test and Sen's Slope Estimates-The Excel Template Application MAKESENS; Finnish Meteorological Institute: Helsinki, Finland. 
Solarski, M., Pradela, A., Rzętała, M. (2011). Natural and anthropogenic influences on ice formation on various water bodies of the Silesian Upland (southern Poland). Limnological Review, 1, 33-44.

Sulikowska, A., Wypych, A., Ustrnul, Z., Czekierda, D. (2016). Zmienność zasobów termicznych w Polsce w aspekcie obserwowanych zmian klimatu. Acta Scientiarum Polonorum. Formatio Circumiectus, 15(2), 127 -139 .

Surdu, C.M., Duguay, C.R., Brown, L.C., Fernández Prieto, D. (2014). Response of ice cover on shallow lakes of the North Slope of Alaska to contemporary climate conditions (1950-2011): Radar remote-sensing and numerical modeling data analysis. Cryosphere, 8, 1, 167-180.
Sziwa, R., Jańczak, J. (2009). Extreme values of ice cover thickness and ice phenomena duration on lakes in Poland. Limnological Review, 9, 2-3, 111-119.

Todd, M.C., Mackay, A.W. (2003). Large-scale climatic controls on Lake Baikal Ice Cover. Journal of Climate, 16, 19, 3186-3199.

Wrzesiński, D., Choiński, A., Ptak, M., Skowron, R. (2015). Effect of the North Atlantic Oscillation on the Pattern of Lake Ice Phenology in Poland. Acta Geophysica, 63, 6, 1664-1684.

Wrzesiński, D., Ptak, M., Baczyńska, A., (2013). Effect of the north atlantic oscillation on ice phenomena on selected lakes in Poland over the years 1961-2010. Quaestiones Geographicae, 32, 3, 119-128.

\section{ZMIANY REŻIMU LODOWEGO JEZIORA JAGODNE (PÓŁNOCNO-WSCHODNIA POLSKA)}

\section{ABSTRAKT}

\section{Cel pracy}

Wskazanie kierunków i tempa zmian reżimu lodowego jeziora Jagodne w latach 1975-2015. Analiza przewidywalności występowania zjawisk lodowych w odniesieniu do stabilności i sezonowości oraz poznanie wzajemnych interakcji pomiędzy parametrami opisującymi reżim lodowy jeziora Jagodne.

\section{Materiat i metody}

Dane wodowskazowe ze stacji IMGW-PIB Jagodne Małe na jeziorze Jagodne, dotyczące: terminów początku i końca zjawisk lodowych, początku i końca pokrywy lodowej oraz grubości pokrywy lodowej z lat 1975-2015. Średnie miesięczne temperatury powietrza ze stacji synoptycznej IMGW-PIB w Mikołajkach z wielolecia 1975-2015. Analiza statystyczna wykonana w oparciu o analizy trendów za pomocą nieparametrycznego testu Manna-Kendalla oraz metodę Colwella.

\section{Wyniki i wnioski}

Przeprowadzone badania wykazały, że jezioro Jagodne na przestrzeni ostatnich dekad cechowało się pewnymi tendencjami do zmian reżimu lodowego. Trendy te należy utożsamiać z sukcesywnym skracaniem sezonu lodowego oraz zmniejszaniem się grubości pokrywy lodowej. Zmiany te jednak w przypadku początków i końca występowania zjawisk lodowych (w tym pokrywy lodowej) oraz miąższości pokrywy lodowej nie są istotne statystycznie. Tylko w przypadku czasu trwania zjawisk lodowych zaobserwowano jego skrócenie, które potwierdzono testem statystycznym Manna-Kendella. Analizowany obiekt reaguje w podobny sposób jak większość jezior, dla których prowadzone były badania, dotyczące zmian zlodzenia. Obserwowany wzrost średnich temperatur w kwietniu wpłynął natomiast na skrócenie czasu występowania zjawisk lodowych, w tym pokrywy lodowej. Odnotowane przemiany będą prowadziły do transformacji jeziora, a jej skutki z uwagi na sieć powiązanych ze sobą relacji (biotycznych i abiotycznych) są trudne do przewidzenia.

Słowa kluczowe: jeziora, zmiany klimatu, reżim lodowy, pokrywa lodowa 